UDC 347.7:339.9

JEL Classification: F15, F55, F42

http://doi.org/10.21272/mmi.2019.3-26

Marcel Kordos,

Ph.D., Alexander Dubcek University in Trencin, Slovak Republic

\title{
BRITISH-SLOVAK FOREIGN TRADE RELATIONS: CONSEQUENCES OF BREXIT
}

Abstract. The possibility of the UK's withdrawal from the European Union has never been more realistic and upto-date since joining the European Communities (EC) as it is today. The UK is facing a unique situation. At present, this depends solely on the capabilities of European and British government officials, who negotiate the terms of withdrawal and future cooperation between the two entities. The main goal of this paper is based on the British Slovak trade relations development analysis to figure out their impact within the Brexit consequences on the future Slovak economy and its current status in international economic relations. The paper also provides a basic overview of Brexit process and its possible impact on the EU's further functioning. Basic data will be drawn from generally accepted institutions, evaluating the UK and Slovak trade and economic performance. To accomplish this goal, methods such as analysis and comparison to illustrate the UK-Slovak foreign trade development, synthesis and logical deduction to discuss the Brexit impact on Slovak economic environment in the future are to be used; data from scientific and professional publications, periodical and non-periodical press. The paper presents the results of an empirical analysis, which showed that because of the size of economic relations between Slovakia and the United Kingdom and the number of goods and services being exported to the UK, the "hard" Brexit will be very unfavourable for Slovak foreign trade due to the possible tariffs being imposed. The research empirically confirms and theoretically proves that it can cause a significant weakening and slowdown in the Slovak economy. Either way, the upcoming Brexit process, that is the withdrawal of Great Britain from the European Union, would have a major impact not only on British, European but also on the world economy. The impact of Brexit on Slovakia's economy will not only be in reducing the possible growth of the economy, but also in employment and price increases.

Keywords: EU single market, Britain's withdrawal from the EU, foreign trade policy instruments analysis, international economics, Slovak economy slowdown prediction, Slovak foreign trade commodity structure analysis.

Introduction. European Union is perceived as a subject of a unique grouping of 28 states whose main benefits are the principles based on solidarity and resulting from the single common market benefits such as the free movement of goods and services, labour and capital. However, financial solidarity in the European Union has become one of the most controversial issues in recent years (Gartner et al, 2017). The redistribution of funds across the European Union is becoming increasingly difficult for people living in prosperous states, and solidarity is no longer such a natural concept. The economic benefits of unrestricted movement of goods, labour and capital are now facing significant resistance. It is precisely the disagreement with the enlargement of European Union's powers on account of the Member States that has become one of the main reasons for British dissatisfaction, which has resulted in a decision to leave the European Union. The withdrawal of Great Britain has been an issue for a long time. Already in 1975, UK residents decided whether they would remain a part of the European Communities (EC). The result was unambiguous at that time, $67 \%$ of the population voted to remain in EC (Fojtikova, 2016; De Castro, T., at al. 2017). Today, the voices of British Eurosceptic parties are growing stronger. The reason for this is further regulation and, in particular, the migration issue. The United Kingdom's European Union Referendum was held in 2016, where voters voted in favor of the UK's withdrawal from the European Union. However, the result of the referendum is irreversible, and $51.9 \%$ of British people voted for the UK's withdrawal from the European Union (BBC, 2019; Drulak, Drulakova, 2014).

The possibility of the UK's withdrawal from the European Union has never been more realistic and upto-date since joining the EC as it is today. The reason for this is the often-unsustainable situation with immigrants in the country, high costs, or bureaucracy from Brussels. By Jovanovic (2014) this is linked to the events in EU in recent years, resulting in an increase in «Eurosceptics», people who disagree with EU

Cite as: Kordos, M. (2019). British-Slovak Foreign Trade Relations: Consequences of Brexit. Marketing and Management of Innovations, 3, 341-353. http://doi.org/10.21272/mmi.2019.3-26 
policy, criticize it and even demand the withdrawal of their own state from the Union. The issue of the UK's and any EU Member State withdrawal at all is a theoretical topic to date since there has never been any withdrawal in the history of the European Union. Every Member State now has a right of withdrawal, and in particular, the advantages and disadvantages of EU membership should be discussed in terms of staying in the EU (Lipkova, Hovorkova, 2018). Today, the European Union is made up of 28 states, different economies. At present, it faces many crises, one of which is the so-called. Brexit - Britain's withdrawal from the EU. The UK is facing a unique situation. At present, this depends solely on the capabilities of European and British government officials, who negotiate the terms of withdrawal and future cooperation between the two entities (Abrham, 2017). Unless new agreements are concluded with the European Union among the individual Member States, including Slovakia, United Kingdom's further political and economic development can only be estimated.

Brexit's impact on foreign trade in individual EU countries, which will have the greatest impact on Britain's exit from the single market, will be distinctive in Slovakia as well. The reason is the share of Slovakia's exports to Britain in terms of total exports, and also as a percentage of GDP. According to the Slovak Ministry of Economy (2019), exports to the United Kingdom account for the largest share of the country's total exports in Ireland (4.17\%), in Slovakia it is $3.27 \%$. Slovakia is also among the most vulnerable countries as regards the share of exports to Britain in relation to GDP. Luxembourg has the largest share in the EU28 - its exports to the United Kingdom make up 10,1\% of GDP and the top 5 is finished by Slovakia with $5,2 \%$.

It is undeniable that the economies on both sides will feel the negative effects of the uncontrolled British exit. The hard performance under the IMF will cause Union countries long-term damage to 1,5 percent of GDP. Slovakia's losses are estimated at 0,4 percent of GDP (Eurostat, 2019). Generally speaking, the direct impact of Brexit on Slovakia will not be drastic, but not negligible. If no free trade agreement is to be negotiated, it could be notable in foreign trade after the negotiations being completed. According to the Slovak Ministry of Economy data, in $2018,6 \%$ of the total Slovak exports headed to Great Britain and $2.5 \%$ of the total imports to Slovakia came from the UK. In 2018, Slovakia exported $4.5 \mathrm{mld}$. EUR to the UK, making it the sixth-largest market for Slovak goods. At the same time, Slovak exports exceed imports by more than 2.7 mld. EUR. But the biggest impact of hard Brexit will not be direct. The overall uncertainty and slowdown in economic growth in the United Kingdom and the Euro area, i.e. Slovakia's main trading partners, will hit the Slovak economy more significantly. The attractiveness of Slovak production can be negatively influenced also by the possible weakening of the British Pound after the Brexit.

The following paper deals with the possible consequences of Brexit for the Slovak Republic, especially the imminent risk of mutual foreign trade relations, which due to Brexit may have a negative trend in the near future. The word "possible consequence» will be very often included in the text, as all that is mentioned here is the result of conjectures and estimates of assumed risks that Slovak economy must be ready for in the context of British-Slovak economic and, in particular, trade relations, as the situation might be totally changed after March 2019.

Literature Review. The most commonly used term nowadays within the EU context is the Brexit, i.e. Great Britain's withdrawal from the EU. The word Brexit was created by combining two words, «Britain» and «Exit». Based on the referendum results, the British government announced that the formal withdrawal procedure will begin on March 29, 2017, to be completed at the latest in early 2019.

UK versus EU or the British-EU symbiosis. When it comes to the European Communities integration process, Britain has never been considered a strong advocate of European integration being held aside from deeper integration, in many cases, however UK membership cannot be considered marginal (Tauser et al, 2015; Zak, 2012). To put in other words, EU membership could be characterized as British interest 
in gaining economic benefits by participating in this European project, but without sharing the membership costs or renouncing any part of its economic or political sovereignty.

Regarding the UK-EU relations, the following characteristics need to be highlighted. First of all, the UK is the second EU largest economy after Germany. The London financial market is the largest in the EU ( $25 \%$ of all services provided within the EU, $40 \%$ of financial services are exported to the Union). More than $50 \%$ of all UK exports go to the EU, while $14 \%$ of imports come from the Eurozone area, and finally, $46 \%$ of all foreign direct investments (FDIs) comes to the UK from the EU and Britain is the second largest FDI recipient from the EU after the US (OECD, 2019).

UK has been an EU Member State since 1 January 1973, when the first enlargement occurred. It is the first country to integrate its system with the European Economic Comunity system and being a part of the EU for 45 years. In such a long time, it is logical that the country system is very closely linked to the EU system, even though UK has kept away from certain integration issues, such as the UK exemption from the obligation to implement the common currency and negotiate the possibility of not joining the Schengen area. UK has also a strong position within the EU single market. Intra-EU trade accounts for $47 \%$ of UK exports. up to $51 \%$ of imports come from the EU Member States (Germany $14 \%$, Holland $7 \%$ and France 5\%) (OECD, 2019).

In term of the initial rounds of talks on the UK's withdrawal from EU, the economic public is interested in the impact of Brexit on UK economy, the future of London as Europe's financial center and the influence of Brexit on financial markets. According to current development trends, UK is inclined to so-called «hard Brexit», which means that UK trade relations will be functioning as a relationship of any other non-member country under World Trade Organization rules (Burda et al, 2017; Sejkora, 2014; Sejkora, Sankot, 2017). To illustrate this issue, almost $12 \%$ of UK GDP is exported to the EU. At the same time, harsh Brexit would mean that the UK would lose access to the EU financial services single market through which banks registered in London serve their clients across the EU market. In 2015, almost 26 billion pounds of financial services, pensions and insurance were exported, representing about 2.5\% of the UK GDP (Danaj et al, 2018). A combination of lower growth. GDP resulting from lower exports of financial services and goods along with lower investment, tax collection or employment would have wider economic consequences. According to Belas, et al (2018) in the absence of favorable agreements with EU, Britain's GDP could fall by about $2.2 \%$ by 2030 . However, in a more optimistic scenario, it says if Britain were to conclude a free trade agreement with EU and the rest of the world, there could be an improvement of $1.6 \%$ of UK GDP by 2030.

The ways how to withdraw from the EU and consequences. Lisbon Treaty was the first to implement a legal mechanism for the EU withdrawal process. Each EU Member State may decide to step out of the integration process. The decision to withdraw from the EU will be taken by the Member state in accordance with its constitutional requirements. Subsequently, it shall notify the European Council of its intention to withdraw from the EU (Zemanova, Drulakova, 2016). On the basis of the European Council's guidelines, EU will conclude with that Member State a withdrawal agreement setting out the withdrawal modalities. The agreement is negotiated by the Commission and concluded by the Council, acting by a qualified majority after the European Parliament has given its consent. The founding treaties shall cease to apply to the leaving State from the date of entry into force of the withdrawal agreement, or, if no agreement is reached, two years after the Member State's notification to withdraw from the EU (Abrham, Lzicar, 2018). The members of the European Council or EU Council representing the leaving State shall not participate in negotiations or decisions of those authorities. Article 50 is a plan for every country that wants it to do so. It was created as part of the Lisbon Treaty - an agreement signed by all EU states became a law Act in 2009 (Lipkova, Braga, 2016). There was no formal mechanism for leaving the EU before this Treaty. It is rather short - only five paragraphs - which state that any EU Member State may decide to leave the $\mathrm{EU}$, and negotiate with the EU on the EU withdrawal; a two-year transition period can be set if both sides 
agree; and that the leaving State cannot participate in internal discussions about leaving the EU (Fojtikova, Stanickova, M. 2017).

It is more than certain that by withdrawing the Member State from the European Union the issue has been finished, and therefore it is appropriate to look further at the effects of country's withdrawal from the Union. As the European Union's integration process continues and the dependence of Member states is reinforced, it is very difficult to define all the consequences of such a striking intervention as the EU withdrawal undoubtedly is (Malec, Abrham, 2016; Abrham et al, 2015; BBC, 2019). In this case, it is necessary to anchor not only the withdrawal of a Member state from EU founding treaties but also to define further the long-term new parameters of the future relationship between the particular state and European Union.

Of course, leaving the EU can have both a negative and a positive impact on a Member State. It is necessary to point out to the administrative problems accompanying the entire EU withdrawal process. In this context, it is also possible to talk about the losses of government autonomy, the area of transnational regulation (Lipkova et al., 2017). At the moment of withdrawal from the European Union, the country would lose enormous influence on European policies and would lose an extremely important representation. Withdrawal would also have an impact on the creation of European legislation, it would impose regulations on the market of goods and services and probably reduce the GDP (Varadzin, 2016.).

The European Union also has an impact on the Member States' public finances, as each Member State may, during its membership, receive fiscal transfers from the EU budget, but must make particular contributions to that budget (Cihelkova, 2016). There is also a risk of a possible loss of impact on macroeconomic policy implementation. In particular, public finances can be improved by leaving a Member State out of the European Union, thanks to the reduction of contributions to the European Union's common budget. The specific size of the financial savings associated with leaving the European Union and minimizing contributions to its common budget is based on a withdrawal agreement from that institution (Mura et al, 2017; Balaz, 2015; Balaz, Hamara, 2016). The advantage of this agreement is largely influenced by the negotiating power of a particular country.

In this context, it is also worth mentioning the positive effects of withdrawal impact from the European Union. The exit from the European Union is very often associated with an effect called: the end of market distortion. When a Member State leaves the European Union, market distortion will begin to decrease and the state can start to benefit from increased efficiency (Hanulakova, Dano, 2018). Market distortion in the European Union is due to two basic factors, such as standards policy and subsidies policy. It is not appropriate to look at the subsidy policy only in terms of financial balance or figures, it is necessary to perceive the specific effects that operate on the market and are distorting it. Standardization leads to a slowdown in development (Balaz, 2015). It should also be pointed out that the national sovereignty of the country will increase as a result of power transfer at the time of withdrawal from the European Union. At the same time, the function of foreign policy will be restored to its full extent, while the country's policy can later be influenced by the country's national policy.

The term Brexit - theoretical exposition. A consultative referendum on withdrawing the UK from the European Union took place on 23 June 2016 in the UK. The British decided that the UK would leave the EU with a $51.9 \%$ vote and $48.1 \%$ would stay (Miklosik et al, 2018; Eurostat.sk, 2019). People's voting is a politically fundamental but formally non-binding initiative, therefore an official announcement by the British government is needed to launch the procedure under the Lisbon Treaty rules. That was done on March 29,2017 , which initiated the withdrawal process as well as the two-year deadline for negotiating terms and conditions for a withdrawal agreement began. Previously, this step was supported by the British Parliament by passing the Act to Activate Article 50 of the EU Treaty. Meanwhile, Britain announced the so-called hard Brexit, which indicates a de facto leaving the EU without maintaining closer formal ties with the EU (Obadi, Korcek, 2016). 
After the referendum results, a debate regarding the possible consequences of Brexit has started. Of course, the world economy was concerned with next social and economic circumstances after Brexit in the UK, specifically, new trade relations between the UK and EU, as they will play a crucial issue in the new future of the UK. The new UK-EU agreement must be agreed and endorsed by all the remaining EU member states, making the negotiation process considerably more difficult (Machkova, Sato, 2017). This means that an agreement must be drawn up to accommodate both the UK and any EU Member State, and no one has reservations about it. Obviously, it is a very difficult task to satisfy each party, so the Brexit process and the acquisition of a new agreement with the Union take two years. In addition to these two years, possible extensions are foreseen until the agreement is concluded by 29 March 2019.

Either way, Brexit will be a significant change in the structure and stability of European Union, and even in its lightest form, it will emerge a new future not only for the United Kingdom but for EU and the world. Brexit is a precedent that has never happened in the past, and therefore nobody in the current situation of negotiations can say with certainty what its consequences will be. Briefly, all the «possible risks» that may arise from 29 March 2019, when the UK is last called a Member State of European Union, must be presented. The consequences of the UK's decision to separate from the EU will largely depend on the type of Brexit. Several authors such as Dano, Lesakova (2018); Krajnakova, Vojtovic (2017); Lazanyi, Bilan, (2017) highlights three ways how the UK can leave the EU.

«Soft Brexit» represents the conclusion of an agreement with EU and provides the possibility to leave some common relations beneficial to both sides and thus to avert the total detachment of UK from the rest of the EU. In the case of soft Brexit, a number of scenarios are mentioned, but so-called is «Strategic Partnership Agreement» preferred (BBC, 2019). In this case, the UK would retain access to the single market and avoid the application of different tariffs and barriers that apply to trade with a third country. The UK would, therefore, continue to be guided by EU regulations and regulations within the trade. But it would also mean that the UK could regain control over national migration rules.

«Hard Brexit» would mean complete separation from the EU and UK will return to the conditions under which it existed and traded before EU accession. The UK will thus abandon participation in the single market and all its legal rules. Also, it means regaining control of the migration system, which includes tightening immigration controls both from the EU and from other countries (Zadrazilova, 2016). Stepping out of the EU Single Market makes UK trade with the EU and countries outside the Union through the rules of the World Trade Organization, with the third country status.

The situation of «cliff edge» occurs when the two-year period prescribed for deciding on all essentials of UK withdrawal without the agreement is to expire. The country will be forced to leave without an agreement with the Union, and this will mean uncertainty at all issues in current negotiations. It is obvious that the UK needs an agreement for its withdrawal. The exit from the block without an agreement would mean an outbreak of chaos especially within the UK and EU foreign trade and economic relations with a negative impact on small and open economies having tide trade and economic ties with the UK like the Slovak Republic (BBC, 2019).

Methodology and research methods. The research task is focused on the analysis of the problematic aspects of mutual trade relations development between Slovak Republic (SR) and United Kingdom (UK) in terms of the Brexit issue affected by the British withdrawal from the European Union and its consequences. The research will be focused on exploring the UK and Slovak economies' operating area in the international economic system as well as the bilateral trade analyses.

In general, this chapter will handle the problematic aspects regarding the economic issues between the UK and Slovakia. The particular issues will consist of following aspects including: First of all, the task is, on the basis of the UK and SR bilateral trade relations and their analysis, to find out whether and to what measure the problematic trade issues between the UK and SR can affect their economic cooperation in the global system of international economics within the Brexit issue. 
To put in other words, the main goal of this paper is, based on the mutual problematic UK - SR trade issues relations within the Brexit consequences, to figure out how the further development of Slovak economy is to be affected by it. The paper is focused on problematic aspect analyses such as the UK and SR common trade agenda, in terms of Slovak foreign trade development with Great Britain along with the export and import commodity structure analysis. The issue is to figure out whether and to what measure the problematic trade issues between the UK and SR can affect the Slovak economy development and its next status within the economic cooperation in the global system of international economic environment especially within the European Union.

The ways of synthetic and analytic methods will be used in the paper such as the analysis and comparison to illustrate the UK-Slovak foreign trade development, synthesis and logical deduction to discuss the impact of Brexit on Slovak economic environment in the future. Subsequently, the analysis will lead to synthesis and prognosis by means of abstraction method eliminating the less important factors in order to set general statements and opinions. In particular, to estimate the next obstacles to be faced within the foreign trade issues and to recommend the activities for Slovak entrepreneurs and companies to eliminate the negative impacts of hard Brexit that would affect their trade relations with British companies. The analysis of data from scientific and professional publications, periodical and no periodical press as well as international economic organizations such as OECD, WTO IMF and World Bank will be primarily used and examined. Basic data will be drawn from generally accepted institutions, assessing the international trend agenda such as National bank of Slovakia, OECD, Slovak Ministry of Economy.

Results. The basic economic impact of Brexit for Slovak economy could an economic slowdown in GDP growth. It is possible to anticipate a slowdown in Slovak GDP growth from one-tenth to two-tenths of a percentage point. A more serious problem is the projected reduction in economic growth in the Eurozone countries area, which may be negatively reflected in Slovak exports.

Brexit's initial impact on Slovakia can be estimated quite well if focused on foreign trade. According to the National bank of Slovakia analysis, due to the restriction of goods flows, the GDP growth in Slovakia will decrease by about $0.1 \mathrm{pp}$. annually, i.e. about $0.34 \%$ cumulatively over 4 years. As shown in Table 1 , by 2020, Brexit could only slow the Slovak economy's growth by 0.34 per cent. This would be indicative of an estimated 5300 fewer jobs created and prices could rise by a further 0.4 per cent. In doing so, the OECD assumes that the growth of the UK economy in case of withdrawal from the European Union could slow down by more than three percentage points cumulatively by 2020 .

Table 1. Illustrative impact of Brexit on Slovak economy

\begin{tabular}{|l|c|c|c|c|c|}
\hline & $\mathbf{2 0 1 6}$ & $\mathbf{2 0 1 7}$ & $\mathbf{2 0 1 8}$ & $\mathbf{2 0 1 9}$ & $\mathbf{2 0 2 0}$ \\
\hline Internal demand & $-0,05$ & $-0,25$ & $-0,32$ & $-0,38$ & $-0,43$ \\
\hline Export of goods and services & $-0,09$ & $-0,50$ & $-0,69$ & $-0,76$ & $-0,81$ \\
\hline Gross Domestic Product & $-0,05$ & $-0,22$ & $-0,28$ & $-0,31$ & $-0,34$ \\
\hline Price level HICP & 0,13 & 0,33 & $-0,42$ & $-0,44$ & $-0,43$ \\
\hline Employment (persons) & $\mathbf{- 2 0 0}$ & $\mathbf{- 1 8 7 1}$ & $\mathbf{- 3 6 2 0}$ & $\mathbf{- 4 4 4 4}$ & $\mathbf{- 5 3 6 7}$ \\
\hline
\end{tabular}

Sources: systematised by the author on the basis of (National bank of Slovakia, 2019)

In the case of reduced GDP growth in the UK, the impact on Slovak economy might not be as significant as exports to the UK account for about 5.5\% of total exports Slovak in 2017 as illustrated in Figure 1. 


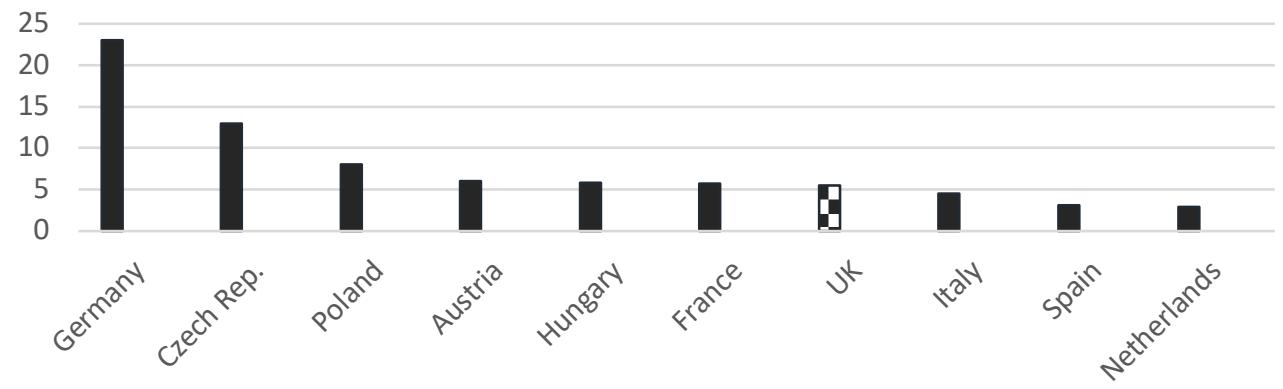

Figure 1. The percentage share of Great Britain on Slovak export in 2017

Sources: systematised by the author on the basis of (Statistical Office of Slovak Republic, 2019)

As shown in Figure 1, the share of Great Britain in Slovak foreign trade is relatively small and the UK is the seventh most important export partner for the Slovak Republic. In 2017 Great Britain accounts for $5.5 \%$ of Slovakia's total exports and $1.6 \%$ of Slovakia's imports. However, Britain's share of Slovak foreign trade has been growing rapidly in recent years. Figure 2 shows that exports are particularly successful, the pace of which is almost 2 times faster than the total export from Slovakia for the last 5 years. On the other hand, the growth of imports from the UK was similar to the growth of total imports in $2012-2017$. Despite the relatively small share of total foreign trade, the trade balance of Slovakia with Britain for 2017 is the second largest (EUR 2.9 billion), just behind Germany.

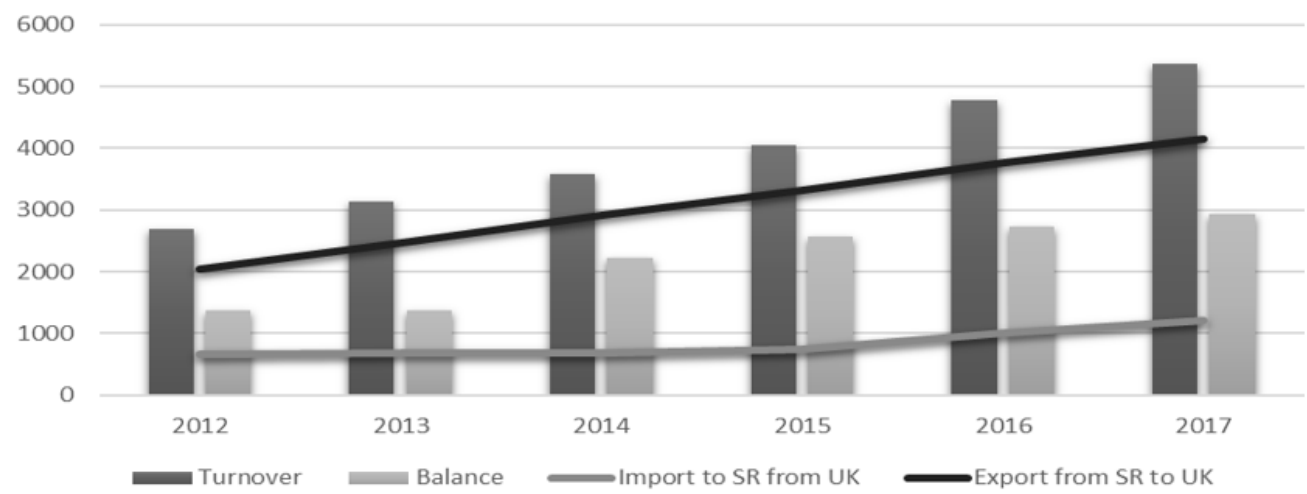

Figure 2. Slovak Foreign trade with Great Britain in millions of EUR in the period of 2012 to 2017

Sources: systematised by the author on the basis of (Statistical Office of Slovak Republic, 2019)

As observed in Table 2, in the period from 2012 to 2017, mutual trade is showing a growing trend (exports of about $11 \%$ and imports of about $8 \%$ ), while the trade balance surplus in Slovakia is also continuously increasing. Slovak exports to the UK in 2017 amounted to $4.2 \mathrm{mld}$. $€$ and imports $1.2 \mathrm{mld}$. $€$.

Traditional export items from Slovakia to the UK are vehicles, electrical machinery, mineral fuels and chemicals. These four commodity groups account for more than $80 \%$ of Slovak exports to the UK. The most exported goods to the UK are cars, which account for almost half of Slovakia's total exports to the UK. The commodity structure of UK imports is dominated by fuels, machinery and electronics. Mineral fuels and oils, electrical equipment and pharmaceutical products make up the largest share of imports. 
Table 2. Illustrative impact of Brexit on Slovak economy

\begin{tabular}{|c|r|r|r|r|r|c|c|}
\hline Millions of EUR & 2012 & 2013 & 2014 & 2015 & 2016 & 2017 & $\begin{array}{c}\text { Index } \\
2016 / 17\end{array}$ \\
\hline Import to SR from UK & 665,14 & 684,21 & 680,58 & 740,01 & 1018,30 & 1217,86 & 1,2 \\
\hline Export from SR to UK & 2036,24 & 2460,13 & 2909,50 & 3318,16 & 3758,23 & 4157,84 & 1,1 \\
\hline Turnover & 2701,38 & 3144,34 & 3590,08 & 4058,17 & 4776,53 & 5375,70 & \\
\hline Balance & 1371,10 & 1775,92 & 2228,92 & 2578,15 & 2739,93 & 2939,98 & \\
\hline
\end{tabular}

Sources: systematised by the author on the basis of (Statistical Office of Slovak Republic, 2019)

Tables 3 and 4 illustrate more detailed commodity structure of United Kingdom's import and export in 2017 as well as the share for Slovakia.

Table 3. Top 6 imported goods to the United Kingdom for 2017

\begin{tabular}{|l|c|c|c|c|}
\hline \multicolumn{1}{|c|}{ Import } & $\begin{array}{c}\text { Total in the bln. } \\
\text { of EUR }\end{array}$ & Total share in \% & $\begin{array}{c}\text { Total Slovak } \\
\text { export share in \% }\end{array}$ & GDP share in \% \\
\hline Cars and motorcycles & 1875,1 & 49,9 & 2,8 & 2,4 \\
\hline Mineral fuels and oils & 145,1 & 3,9 & 0,2 & 0,2 \\
\hline TV sets & 695,0 & 18,5 & 1,0 & 0,9 \\
\hline Heating boilers & 87,4 & 2,3 & 0,1 & 0,1 \\
\hline Electrical equipment & 90,0 & 2,4 & 0,1 & 0,1 \\
\hline chocolate and products made of it & 26,0 & 0,7 & 0,0 & 0,0 \\
\hline others & 837,6 & 22,3 & 1,2 & 1,1 \\
\hline Import to UK in total & $\mathbf{3 7 5 6 , 2}$ & $\mathbf{1 0 0 , 0}$ & $\mathbf{5 , 5}$ & $\mathbf{4 , 8}$ \\
\hline
\end{tabular}

Source: systematised by the author on the basis of (Statistical Office of Slovak Republic, Slovak Ministry of Economy, 2019)

Table 4. Top 5 exported goods from the United Kingdom for 2017

\begin{tabular}{|l|c|c|c|c|}
\hline \multicolumn{1}{|c|}{ Export } & Total in bln. of EUR & Total share in \% & $\begin{array}{c}\text { Total Slovak import } \\
\text { share in \% }\end{array}$ & GDP share in \% \\
\hline Mineral fuels and oils & 311,0 & 30,5 & 0,5 & 0,4 \\
\hline Gaming devices & 47,8 & 4,7 & 0,1 & 0,1 \\
\hline Pharmaceutical products & 83,7 & 8,2 & 0,1 & 0,1 \\
\hline Cars and their parts & 103,0 & 10,1 & 0,2 & 0,1 \\
\hline Electronics & 26,6 & 2,6 & 0,0 & 0,0 \\
\hline others & 446,1 & 43,8 & 0,7 & 0,6 \\
\hline Export from UK in total & $\mathbf{1 0 1 8 , 2}$ & $\mathbf{1 0 0 , 0}$ & $\mathbf{1 , 6}$ & $\mathbf{1 , 3}$ \\
\hline
\end{tabular}

Source: systematised by the author on the basis of (Statistical Office of Slovak Republic, Slovak Ministry of Economy, 2019)

The main export items to the UK in r. 2017 were cars (49\%) also in the share of exports from Slovakia (2.8\%); electrical machinery and equipment $(2.4 \%)$; sound recorders, TV images, their components $(18.5 \%)$, mineral fuels, mineral oils $(3.9 \%)$, nuclear reactors, boilers, machinery and mechanical appliances; parts thereof $(2,3 \%)$.

In the commodity structure of UK imports in 2017 was dominated by mineral fuels, mineral oils (30\%), electrical machinery and equipment; sound recorders, TV image recorders, $(2,6 \%)$, pharmaceuticals $(8,2 \%)$ and automobiles and parts and accessories $(10,1 \%)$.

As argued by the Ministry of Economy of Slovak Republic (2019) the UK's share of foreign direct investment in Slovakia has been low in the last few years. Great Britain's most significant investments in Slovakia include: Tesco - Store, (retail), Citibank (financial services), Slovalco (engineering industry), 
Shell Slovakia (fuel distribution), Glaxo-Smith-Cline Slovakia (pharmaceutical industry), Core Computer (information technology), Brown - Immo Slovakia, (rental properties), Sedwick Slovakia (personnel agency), IMET, Topos Tovarniky (wholesale bearings and their components), CP Holding - SL'K Piestany (spa), Aqua City Poprad (spa / tourism), Hi-Technology Moldings (plastics processing), BAE (arms and aircraft industry), Clamason Slovakia, (engineering industry), SCS (rental of machinery), EC Harris (consultancy - PPP projects), Grafton Recruiting (personnel agency) and Box Perfect (packaging production). The United Kingdom contributed only $1 \%$ of total FDI to foreign direct investment in Slovakia. Thanks to the investment of Jaguar Land Rover, which is about to invest $1.4 \mathrm{bln}$. Euros to build a new plant, this percentage will increase and the UK will become one of the largest investment donors to Slovak economy.

Discussion. It could be taken for granted that the British decision to leave the EU especially the decision on «hard Brexit» will crucially affect not only the British economy but also the EU countries, including Slovakia. As mentioned above, the overall impact is currently complicated, as it will depend not only on the results of negotiations on the UK's exit from the EU but also on possible financial market turmoil. At first side, it could be said that Slovakia does not have to worry about the greater direct impact of Brexit on its economy. The exit of the United Kingdom from the EU block will be likely to slow the EU's economic growth by tenths of a per cent in upcoming years. However, the key issue will be how the economy of Germany, which is Slovakia's largest trading partner, will cope with the withdrawal of the UK from the EU. Also, the uncertainty that has arisen can harm the already trust in the European Union in terms of international economic relations, which is not good news for the EU's economic growth. The decline in confidence can have a negative impact on investment and consumption in continental Europe.

According to the paper analyzes outcomes, the growth of the UK economy in case of exit from the EU could slow down cumulatively by 2020. The direct impact (stemming from the reduced growth of UK's GDP) on Slovak economy might not be significant in this case, as Slovak export to the UK within the Slovak export territorial structure, does not take up a large proportion of Slovakia's total exports. However, the projected reduction in economic growth in the Eurozone area would additionally affect Slovak exports, to a lesser extent also domestic economic sectors being mostly export-oriented.

Based on the carried out analysis of the foreign trade impact between Great Britain and the Slovak Republic, it is possible to assume the three possible development scenarios within the influence of Brexit on the Slovak economy. The optimistic scenario implies calming down the situation, reducing uncertainty and continuing existing business relations with Great Britain. A realistic scenario observes the creation of trade barriers, the persistence of uncertainty in EU. This can lead to a reduction in foreign demand in the next four years. In this case, due to the lower foreign demand, especially in the UK because of tariffs and quotas having been implemented on goods and services being traded between UK and EU, production in Slovak Jaguar Land Rover plant is expected to start slowdown in after 2019. The pessimistic scenario assumes a stronger disruption of trade relations with Britain, a recession in the UK and a slowdown in growth in the EU. This scenario would be largely reflected in the cumulative decline in foreign demand dynamics after 2019. This scenario would also mean a reduced number of cars being produced at the Jaguar Land Rover after 2019.

When the realistic scenario assumptions are to be met, the Slovak GDP growth will be lower in 2019. Cumulative GDP loss could reach $0.5 \%$ in this case. Employment would be cumulatively lower by $0.2 \%$ (OECD, 2019; Tauser, Cajka, 2014). Also, in case of the free movement of labour between Britain and Slovakia, the return of Slovak workers from the UK to Slovakia could be expected, which would also have a negative impact on the Slovak economy. On the one hand, the supply of skilled labour will increase, while unemployment may increase as well. Currently, around 80,000 Slovaks live in UK (Tupa, Vojtovic, 2018.).

As findings in the analytical part of this paper show, cars signify up to $50 \%$ of Slovakia's total exports 
to the UK. This indicates that Brexit is likely to be a big issue in Slovakia's car production. Slovak car manufacturers exports to Great Britain is about to be stagnating in 2019. Great Britain has long been one of the most important business partners for PSA automotive Trnava and Kia automotive in Zilina. According to Eurostat (2019) data in 2017, PSA exported 6.8 per cent of production to the UK in the first ten months of 2017, while in 2018 exports fell to 5.1 per cent in the same period. In the first six months of 2018, Kia exported 14 per cent of its output to the UK, about 24,000 vehicles. If necessary, manufacturers need to be prepared to react flexibly to the emerging situation by diversifying exports to other markets. Britain's customers have already reduced the demand for vehicles produced by KIA Zilina since the beginning of the year of 2018. The fallouts of Brexit in Slovakia could be even bigger if it also hit the newly opened Jaguar production line in Land Rover corporation in Nitra. Brexit, which is due to take place at the end of March 2019, could, without Britain's agreement with the EU, in Slovakia threaten several thousand jobs not only in the automotive industry but also in the downstream subcontractors.

In the long run term, Brexit will mean a long-term slowdown in gross domestic product growth for the UK economy, which will also be reflected in the growth of unemployment in Britain. In any case, Slovakia will not avoid the adverse economic impacts of GDP, employment and international trade. The negative economic, financial and geo-economics consequences can be felt by the European Union and its members in different fields. Optimistic scenarios predict a loss of about half a million jobs and a $3 \%$ decline in British GDP by 2020 (Bilan et al, 2017; Bilan et al, 2018). More pessimistic scenarios predict a drop of approximately one million jobs and a 5\% decline in British GDP. Slovakia as a very open economy will certainly not avoid this impact. One of the indirect impacts may be the return of a large number of Slovaks from the UK labor market to Slovakia. Another indirect impact for Slovakia may be the fact that Brexit means the withdrawal of a member of the Union, which has promoted modernization and progressive economic reforms. By leaving the EU, Britain can reduce the reformative efforts and innovation potential that the country has represented in the Block.

Based on the obtained results and findings from discussion the following estimates and recommendation could be offered. It could be predicted that Britain's withdrawal from the EU will slow down the Slovak economy by several tenths of a percent of GDP. The main impact of the expected «hard Brexit», which the new British Prime Minister Boris Johnson regards as binding on 31 October 2019, is expected in the first half of 2020. Overall stabilization is expected within the twelve months of Brexit, i.e. by the Autumn of 2020. This time will serve to stabilize supply chains. Overall, Brexit will mean a shortterm fluctuation for the economy, which by itself cannot lead to a recession in Slovakia.

Slovak companies are most worried about the decline in orders due to the weakening of the British Pound, the worsening of economic situation in Britain and the implementation of non-tariff barriers. They are also threatened by imposing the customs duties and the complications associated with customs procedures and the carriage of goods. Slovak companies that are actively preparing for Brexit must look for alternative suppliers, customers and employees on the European continent. They also must start to stock up at least three to four months in advance. They also have to keep informing their UK customers that they will not be able to guarantee the agreed deadlines due to possible supply problems. In addition to tariffs, non-tariff trade barriers will also play a significant role in foreign trade. It's about different regulatory requirements, new administrative formalities in terms of permits or licenses, as well as the validity of certificates obtained by firms before the date of Brexit. Estimates of the direct and indirect role of non-tariff trade barriers are very difficult to quantify. In the first days after the British withdrawal from the EU there is a risk of paralyzing transport and delivery of goods. The production and supply chains operate in the so-called just-in-time mode (the parts or parts are brought directly from the truck to the factory) and the delays in supply will lead to production downturns if companies do not sufficiently stock up. Slovak government must also assist in eliminating these problems and burdens in enhancing the economic diplomacy activities and instruments, especially for small and medium-sized enterprises, in cooperation 
with the Ministries such as Foreign Affairs and Economy, the Slovak Chamber of Commerce and the SARIO - Slovak Export and Investment Promotion Agency.

Conclusions. This paper was dealing with the issue regarding the significant impacts of Brexit not only on the European economy but also on the Slovak economic environment. As far as foreign trade is concerned, the United Kingdom has always been one of the major trading partners for Slovakia, which can be proven by the smooth trade relations in recent years and decades. Although everything depends on the final form of the Brexit treaty, the main goal will be to remove regulatory barriers or various constraints that could significantly affect future economic and trade relations in a negative aspect. The main focus will probably be on the automotive industry. The upcoming Brexit process, that is, the withdrawal of Great Britain from the European Union would have a major impact not only on British, European but also on the world economy. The impact of Brexit on Slovakia's economy will not only be in reducing the possible growth of the economy, but also in employment and price increases.

In conclusion, due to the size of economic relations between Slovakia and United Kingdom and the number of goods and services being exported to the UK, the «hard» Brexit will be very unfavourable for Slovak foreign trade. It can cause a significant weakening and slowdown in the Slovak economy. Products that are currently exported to the UK will need to be placed on new export markets inside the integration block, or production and exports will slow down or stop. Slovakia may suffer a significant loss and decline in foreign trade. Well, that's the worst option that doesn't have to happen.

Further research will be devoted to exploring the role of Brexit within the EU migration policy. Taking into account the issues of labor movement between the UK and Slovakia crucial emphasis should be also paid to researching peculiarities of Slovak workers' status in UK and UK workers' status in Slovakia within the social and economic sustainable development fallouts.

\section{References}

Abrham, J. 2017. Project management and funding in the euroregions, Polish Journal of Management Studies, 16(1): 7-20. doi:10.17512/pjms.2017.16.1.01

Abrham, J., Bilan, Y., Krauchenia, A., and Strielkowski, W. 2015. Planning horizon in labour supply of Belarusian small entrepreneurs (vol 28, pg 773, 2015), Economic Research-Ekonomska Istrazivanja, 28 (1): I-I. doi: 10.1080/1331677X.2015.1115638

Abrham, J., and Lzicar, P. 2018. Risk management in the sustainable development: Analysis of a selected key industry. Journal of Security and Sustainability Issues, 8(2): 171-180. doi:10.9770/jssi.2018.8.2(5)

Balaz, P., and Hamara, A. 2016. Export Dependency of Slovakia on German's Economy. Politicka Ekonomie, 64 (5): $573-590$.

DOI: $10.18267 /$ j.polek.1088

Balaz, P. 2015. Japan's economy in the 21st century. Trends and challenges. Ekonomicky Casopis, 63 (8): $869-872$.

Belas, J; Gavurova, B; Kocisova, K; and Delibasic, M. 2018. The Relationship between Asset Diversification and the Efficiency of Banking Sectors in EU Countries. Transformations in Business \& Economics, 17 (3C): 479-496.

Bilan, Y., Gedek, S., and Mentel, G. 2018. The Analysis of Oil Price and Ruble Exchange Rate. Transformations in Business \& Economics, 17 (3): 195-205.

Bilan, Y., Mishchuk, H., and Dzhyhar, T. 2017. Human capital factors and remuneration: Analysis of relations, modelling of influence. Business: Theory and Practice, 18: 208-214. doi:10.3846/btp.2017.022

Burda, P., Abrham, J., and Horvathova, Z. 2017. Factors influencing online civic participation in mid-sized czech towns. Transformations in Business and Economics, 16(2B): 607-618.

Cihelkova, E. 2016. Formation of the theoretical framework for the comparative analysis of post-socialist countries. Agricultural Economics (Czech Republic), 62(9): 407-420. doi:10.17221/18/2016-AGRICECON

Danaj, A., Lazanyi, K., and Bilan, Y. 2018. Perceptions and Implications of Immigration in France - Economic, Social, Political and Cultural Perspectives, Economics \& Sociology, 11 (3): 226-247. doi: 10.14254/2071-789X.2018/11-3/14

Dano, F., and Lesakova, D. 2018. The role of environmental stimuli in shopping evaluation and responses. Ekonomicky Casopis, 66(5): 465-478

De Castro, T., Vlckova, J., and Hnat, P. 2017. Trade and investment relations between the Czech Republic and China: The Czech Republic as a gateway to the EU? Society and Economy, 39 (4): pp. 481-499. doi: 10.1556/204.2017.39.4.2 
Drulak, P., and Drulakova, R. 2014. The richness of the liberal tradition in international relations: Karl Deutsch on political community and the European integration. International Relations, 28(3): 333-349. DOI: 10.1177/0047117814545951

Fojtikova, L. 2016. Trends in the revealed comparative advantages of the EU member states, Economic Annals-XXI, 161(910): 7-11. doi: https://doi.org/10.21003/ea.V161-02

Fojtikova, L., and Stanickova, M. 2017. The EU member states export competitiveness and productivity, Politicka Ekonomie, 65(6): 669-689. doi: 10.18267/j.polek.1169

Gartner, M., Sadilek, T., and Zadrazilova, D. 2017. Cross-cultural adaptability in a sample of international university students in prague - gender and culture effect. Journal of Applied Economic Sciences, 12(3): 893-906.

Hanulakova, E., and Dano, F. 2018. Circular Economy as a New Managerial Approach. AD ALTA-Journal of Interdisciplinary Research, 8 (1): 95-98.

Jovanovic, M. N. 2014. The Economics of European Integration, 2nd Revised edition. Cheltenham UK: Edward Elgar Pub. Krajnakova, E.; and Vojtovic, S. 2017. Struggles of Older Workers at the Labour Market. Economics \& Sociology, 10 (1): 319-333.

Lazanyi, K., and Bilan, Y. 2017. Generetion z on the labour market - do they trust others within their workplace? [Pokolenie z na rynku pracy - Czy w swoim miejscu pracy ufają innym?] Polish Journal of Management Studies, 16(1): 78-93. doi:10.17512/pjms.2017.16.1.07

Lipkova, L.; and Braga, D. 2016. Measuring Commercialization Success of Innovations in the EU, Marketing and Management of Innovations, 4: 15-30.

Lipkova, L.; and Hovorkova, K. 2018. Economic situation in Norway after the outbreak of the global financial and oil crises in the context of EU integration trends, Economic Annals-XXI, 169(1-2): 12-14.

Lipkova, L., Gress, M., and Poncarova, A 2017. Tax systems in the Czech Republic and the Slovak Republic: comparison with an emphasis on income tax. Economic Annals-XXI, 165 (5-6): 47-5. doi: 10.21003/ea.V165-10

Machkova, H.; and Sato, A. 2017. Analysis of Competitiveness of Belgian Sugar Industry, Listy Cukrovarnicke a Reparske, 133(12): 390-392.

Malec, L., and Abrham, J. 2016. Determinants of tourism industry in selected European countries: a smooth partial least squares approach, Economic Research-Ekonomska Istrazivanja, 29(1): 66-84. doi: 10.1080/1331677X.2016.1156554

Miklosik, A., Kuchta, M., and Zak, S. 2018. Monetising Content through Delivery of Advertisements: The Case of Ad Blockers, AD AL TA-Journal of Interdisciplinary Research, 8(1): 175-179.

Mura, L.; Haviernikova, K.; and Machova, R. 2017. Empirical Results of Entrepreneurs' Network: Case Study of Slovakia. Serbian Journal of Management, 12 (1): 121-131.

Obadi, S. M.; and Korcek, M. 2016. The «Revealed» Comparative Advantage and Competitiveness of the EU's International Trade visa vis the USA, Ekonomicky Casopis, 64(5): 397-422.

Sadilek, T., and Zadrazilova, D. 2016. Current trends in german sugar industry. [Soucasné trendy německého cukrovarnictvi] Listy Cukrovarnicke a Reparske, 132(12), 390-393.

Sejkora, J. 2014. Poor Economics: A Radical Rethinking of the Way to Fight Global Poverty, Ekonomicky Casopis, 62(4): 431435.

Sejkora, J., and Sankot, O. 2017. Comparative advantage, economic structure and growth: The case of Senegal, South African Journal of Economic and Management Sciences, 20(1), Article Number: a1685. doi: 10.4102/sajems.v20i1.1685

Tauser, J., Arltova, M., and Zamberský, P. 2015. Czech exports and german GDP: A closer look, Prague Economic Papers, 24(1): 17-37.

Tauser, J., and Cajka, R. 2014. Hedging techniques in commodity risk management, Agricultural Economics (Czech Republic), 60(4): 174-182

Tupa, M.; and Vojtovic, S. 2018. Impact of Brexit on the migration in The UK. AD ALTA-Journal of Interdisciplinary Research, 8 (2) 306-309.

Varadzin, F. 2016. Global Public Goods and Integration. In Proceedings of the 3rd International Conference on European Integration 2016 (ICE/ 2016), 2016, 1052-1059

Zak, S. 2012. International Marketing: Theory, Practices and New Trends, Prague Economic Papers, 21 (2): 251-254

Zemanova, S., and Drulakova, R. 2016. Making Global Goals Local Business in V4 Countries: V4 Entrepreneurs and the UN Global Compact, In Globalization and its Socio-Economic Consequences, 16th International Scientific Conference Proceedings, PTS I-V, 2490-2497.

Eurostat.sk. 2019. [online] [cit. 2019-08-20]. Retrieved from: www.eurostat.sk

Statistical Office of Slovak Republic. 2019. [online] [cit. 2019-03-11]. Retrieved from: www.statistics.sk/

Ministry of Economy of Slovak Republic. 2019 [online] [cit. 2018-08-25]. Retrieved from: www.vlada.gov.sk/ministerstvohospodarstva-sr/

OECD. 2019 [online] [cit. 2019-03-15]. Retrieved from: www.oecd.org

BBC. 2019. [online] [cit. 2019-03-14]. Retrieved from: http://www.bbc.com/news/

National bank of Slovakia - NBS. 2019. [online] [cit. 2019-03-15]. Retrieved from: https://www.nbs.sk/_img/Documents/_komentare/AnalytickeKomentare/2016/AK36_Brexit_2018.pdf 
Марсель Кордош, Ph.D., університет Олександра Дубчека в Тренчині (Словацька Республіка). Британсько-словацькі торгові відносини: наслідки BREXIT

Наслідки виходу Великобританії з Європейського Союзу наразі досліджуються низкою вчених. При цьому значна частина дослідждень присвячено питанням подальшого економічного розвитку Великобританії в умовах трансформмаційних процесів. У статті визначено, що домовленості та рішення європейських та британських урядів $є$ висхідною точкою майбутньої співпраці між двома суб'єктами. Основною метою статті $€$ аналіз розвитку торговельних відносин між Великобританією та Словаччиною в умовах трансформаційних процесів викликаних BREXIT. Автором проаналізовано вплив BREXIT на економіку Словаччини та її конкурентоспроможність на міжнародній арені. У статті визначено особливості процесу BREXIT, його наслідки та їх вплив на подальше функціонування Словаччини, Великобританії та ЄС в цілому. Інформаційну базу дослідження сформовано на основі статистичних даних про результати торговельно-економічних відносин Великобританії та Словаччини, досліджень наукових та фахових видань. Для досягнення поставленої мети авторами використано такі методи дослідження, як: аналіз та порівняння для визначення тенденцій розвитку торговельних відносин між Великобританією та Словаччиною; синтезу при оцінюванні впливу BREXIT на економічний стан Словаччини. Емпіричні результати дослідження свідчать, що «жорсткі умови» BREXIT матимуть негативний вплив на розвиток словацької зовнішньої торгівлі. Визначено, що найбільш суттєвий вплив матиме введення нових митних тарифів, що спровокує зниження обсягу товарів та послуг, які експортуються Словаччиною до Великобританії. Отримані результати підтверджують та теоретично доводять, що процеси BREXIT спровокують уповільнення розвитку економіки Словаччини. Авторами наголошено, що процеси BREXIT матимуть негативний вплив не лише на розвиток британської та європейської економіки, але й світової. Вплив BREXIT на економіку Словаччини проявлятиметься не лише у зниженні темпів ї̈ зростання, а й у підвищенні цін.

Ключові слова: єдиний ринок $Є С$, вихід Британії з ЄС, зовнішньоекономічна політика, міжнародна економіка, прогнозування, зовнішня торгівля, Словаччина.

Manuscript received: 10.07.2019

(C) The author(s) 2019. This article is published with open access at Sumy State University. 